\title{
HOW HAS THE INDONESIAN STOCK MARKET PERFORMED DURING COVID-19 OUTBREAKS?
}

\author{
Doddy Setiawan \\ Faculty of Economics and Business, Universitas Sebelas Maret \\ Center for Fintech and Banking, Universitas Sebelas Maret \\ Taufiq Arifin \\ Faculty of Economics and Business, Universitas Sebelas Maret \\ Center for Fintech and Banking, Universitas Sebelas Maret \\ Y Anni Aryani \\ Faculty of Economics and Business, Universitas Sebelas Maret \\ Josephine Tan-Hwang Yau* \\ Faculty of Economics and Business, Universiti Malaysia Sarawak
}

\begin{abstract}
This paper analyzes the stock market reaction towards the Covid-19 pandemic by using a sample of Indonesian listed firms. In general, we document a significant negative cumulative abnormal returns when the Indonesian President announces the first case of Covid-19 in Indonesia. This effect remains ten days (weaker) after the announcement. However, we only find a short-term effect on the finance industry. While the explanation is still unclear, the investors may observe that the economic impact on the finance industry may arise in the long-run.
\end{abstract}

Keywords: covid-19, economic impact, market reaction, abnormal return

Received: 17 July 2020

Accepted: 2 August 2021

https://doi.org/10.33736/ijbs.4312.2021

\section{INTRODUCTION}

Recently, we have observed an unexpected reaction of the business environment on the global pandemic of Covid-19. The outbreaks of Covid-19 in several countries have sparked concerns among investors whether the virus outbreak will be a pandemic and thus may significantly slowing down economics. At the end of February, there are more than eighty thousand cases of Covid-19 in 32 countries and causing more than two thousand death. ${ }^{1}$ Therefore, on March $11^{\text {th }}, 2020$, the

\footnotetext{
- Corresponding author: Faculty of Economics and Business, Universiti Malaysia Sarawak, 94300 Kota Samarahan, Sarawak, Malaysia; Tel: +6082-584370; Email address: ythjosephine@unimas,my

${ }^{1}$ See https//coronavirus.jhu.edu/map.html. So far, the virus has infected more than seven million humans and caused more than four hundred thousand deaths (last accessed June 10, 2020).
} 
World Health Organization (WHO) has labelled the Covid-19 outbreak as a global pandemic. ${ }^{2}$ Globalization has increased the likelihood that the virus spreading in one country will spread rapidly in another country (Ali et al., 2020; Smith, 2006).

The emergence of the pandemic makes the authorities around the world pay special heed. The lockdown decision and tightened restrictions have already been taken by over 136 countries to decelerate the pandemic. However, these policies will also lead to economic consequences such as stalled production and distribution of goods and services (De Vito \& Gómez, 2020). The United Nations Development Programme (UNDP) expects a reduction of income around USD 220 billion in developing countries. ${ }^{3}$ Together with enormous social and health costs, the pandemic may cause a global destructive economic crisis (Goodell, 2020; Sharif et al., 2020).

While the economic impacts are still difficult to quantify, the pandemic results in negative movements of the financial market (Ashraf, 2020b; Erdem, 2020; Mazur et al., 2020; Zhang et al., 2020) and increase volatility (Haroon \& Rizvi, 2020). The market reacts negatively to the announcement of social distance policy since it has a negative effect on economics (Ashraf, 2020a). The effects have been shown in the market crash in the US, Europe, and several Asian countries as responses to the Covid-19 crisis. Similarly, Indonesia's stock dropped harshly indicates that the investors left the markets after the Indonesian President announce the first case of Covid-19. The decline continued until the end of March and then followed with volatile weeks. Figure 1 plots the daily index before and after the announcement. The regulators have released a package of policies to intervene in the market and anticipate the potential economic costs of the pandemic.

Figure 1. Jakarta Composite Index (before and after the announcement date of Covid-19 first case)

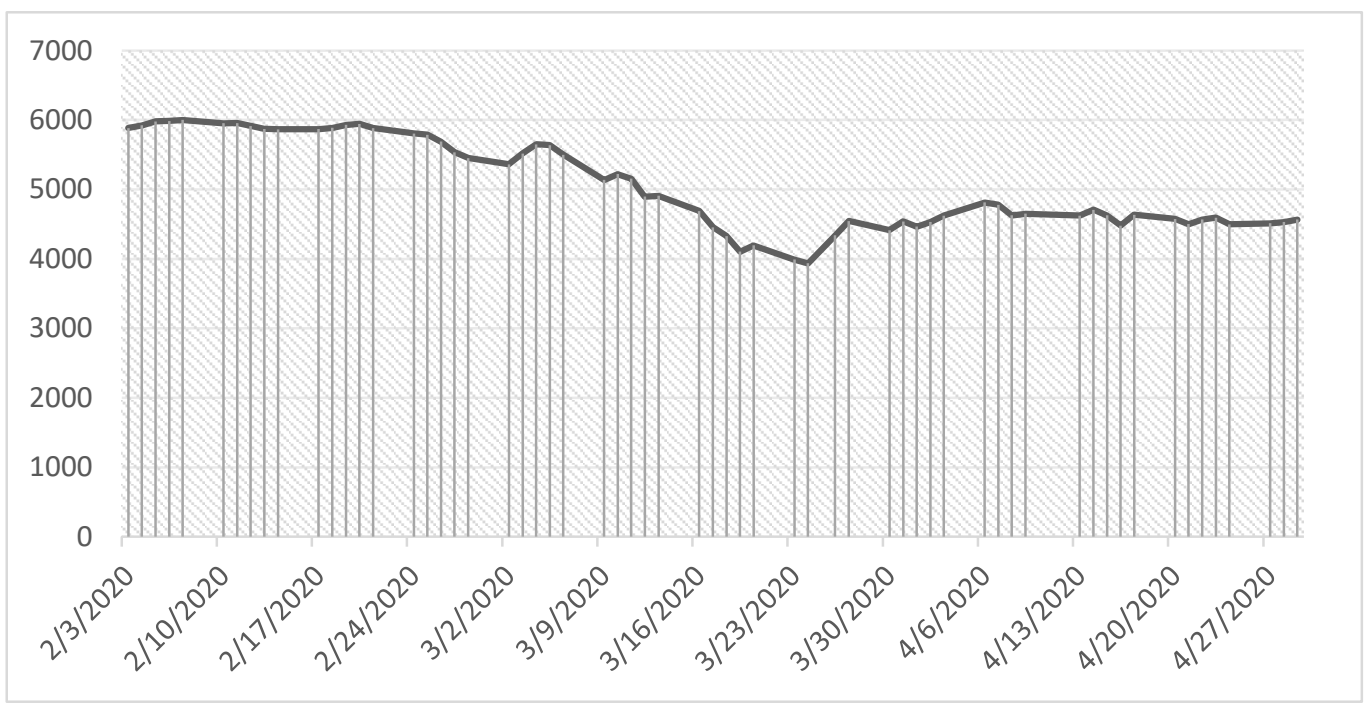

\footnotetext{
${ }^{2}$ See https://www.bbc.com/news/world-51839944 (last accessed June 10, 2020).

${ }^{3}$ See https://www.undp.org/content/undp/en/home/news-

centre/news/2020/COVID19_Crisis_in_developing_countries_threatens_devastate_economies.html (last accessed July 5, 2020).
} 
This outlook on the market reaction of Covid-19 pandemic will shed light on how investors' reactions during external shocks. To quantify the market reaction, we use short term event-study methodology. The abnormal return reflects the investors' perception towards an external shock, e.g., covid-19 pandemic, controlling for the normal return before the event, at a given point in time. To compute the abnormal return, we use single index model (market model) and historical mean model. A total of 541 listed-firms has been included in our our sample, for which we are able to obtain the stock prices.

Our estimations of the cumulative abnormal returns reveal interesting patterns. We observe a weak negative market reaction before the announcement date, which indicates that investors already perceive the global dominos' effect of Covid-19 pandemic. In general, for the full sample, we find Indonesian listed firms showed a negative market reaction towards the Covid-19 first case announcement. In particular, this effect remains ten days (weaker) after the announcement. However, we only find a short-term effect on the finance industry. While the explanation is still unclear, the investors may expect the negative impacts on the finance industry are more likely to occur in the long-term.

The remainder of the paper proceeds as follows; Sections 2 presents our empirical method, Section 3 discusses the results, and Section 4 concludes the study.

\section{METHODOLOGY}

We obtain our stock price data from the Indonesia Stock Exchange (BEI). Since our main objective is to examine the market reactions towards the Covid-19 pandemic, we limit our sample only for Indonesian listed firms. Yahoo! Finance provides adjusted-daily stock price information. To be included in the sample, a stock must have been listed and actively traded in the Indonesian Stock Exchange with an observation period (30 days before and after event date). We then classify our sample using the Indonesian Stock Exchange industry classification to identify the market reaction of each industry. There are nine industries in this classification system; agriculture, mining, chemistry, various industries, consumer goods, property, infrastructure \& utilities, Finance, and trading. Our final sample consists of 541 firms, with the majority of listed firms are from trading industries which account for approximately $22 \%$ of the total sample.

We examine the market reaction using the standard event-study methodology. As a major tool for examining market efficiency, event-study method examines and draws inferences about the impact of particular event over several periods. We select March $3^{\text {rd }}, 2020$, as our event date when the President of Indonesia, Joko Widodo, announced the first case of Covid-19. Our estimation window is 30 days before the event date to avoid any confounding effects. Then we compute abnormal return using single index model (market model) and historical mean model.

Following MacKinlay (1997), we use the following equation to estimate the abnormal returns (ARs) using the Single Index Model:

$$
A R_{i, t}=R_{i, t}-\left(\alpha_{i}+\beta_{i} R_{m, t}\right)
$$


In the Single Index Model, the normal return depends on the $\alpha_{i}, \beta_{i}$, and the market return $\left(R_{m, t}\right)$. $\beta_{i}$ is calculated over the estimation period returns. Our second measure specification to estimate the abnormal returns is historical mean model following Brown and Warner (1985). According to this model, the stock's historical mean return represents the expected normal performance unconditioned to the event as shown below:

$$
E\left(R_{i, t} \mid X_{t}\right)=\mu_{i}
$$

For each model, we estimate cumulative abnormal return by summing abnormal return for each event windows $(-10,-2),(-1,0),(-1+1),(-3,+3),(-5+5),(-10,+10)$, and $(+1,+10)$, where 0 indicates the event date. Once normal returns are calculated, thus we obtain the cross-section aggregation of the ARs (AAR) using the following formula:

$$
A A R_{t}=\frac{1}{N} \sum_{i=1}^{N} A R_{i, t}
$$

Finally, the cumulative abnormal return (CAAR) for a sector I during the event window [t1:t2] surrounding the event day $\mathrm{t}=0$, is calculated as follows:

$$
\operatorname{CAAR}\left(t_{1}, t_{2}\right)=\sum_{t=t_{1}}^{t_{2}} A A R_{t}
$$

Under the null hypothesis, we posit that the mean of cumulative abnormal return around the event date, the announcement of Indonesian first case of Covid-19, is equal to zero. Therefore, we use tstatistics to test our hypothesis whether the estimated CARs in particular times interval are equal to zero.

\section{RESULTS AND DISCUSSION}

Our presumption is that the Covid-19 pandemic will be negatively perceived by investors as the impact of pandemics has been considerably enormous. There are concerns that the pandemic may cause a lockdown policy and lead to the economic slowdown. In 2003, with around 10.000 infected individuals, the economic cost of SARS (severe acute respiratory syndrome) was estimated at around USD 30-100 billion (Smith, 2006). With the greater number of cases, the Covid-19 pandemic will cause a greater risk and economic cost in the global financial markets (Zhang et al., 2020). The study of De Vito and Gómez (2020) also shows the negative liquidity (Haroon \& Rizvi, 2020) and cash burn effects of the pandemic across the industries. 


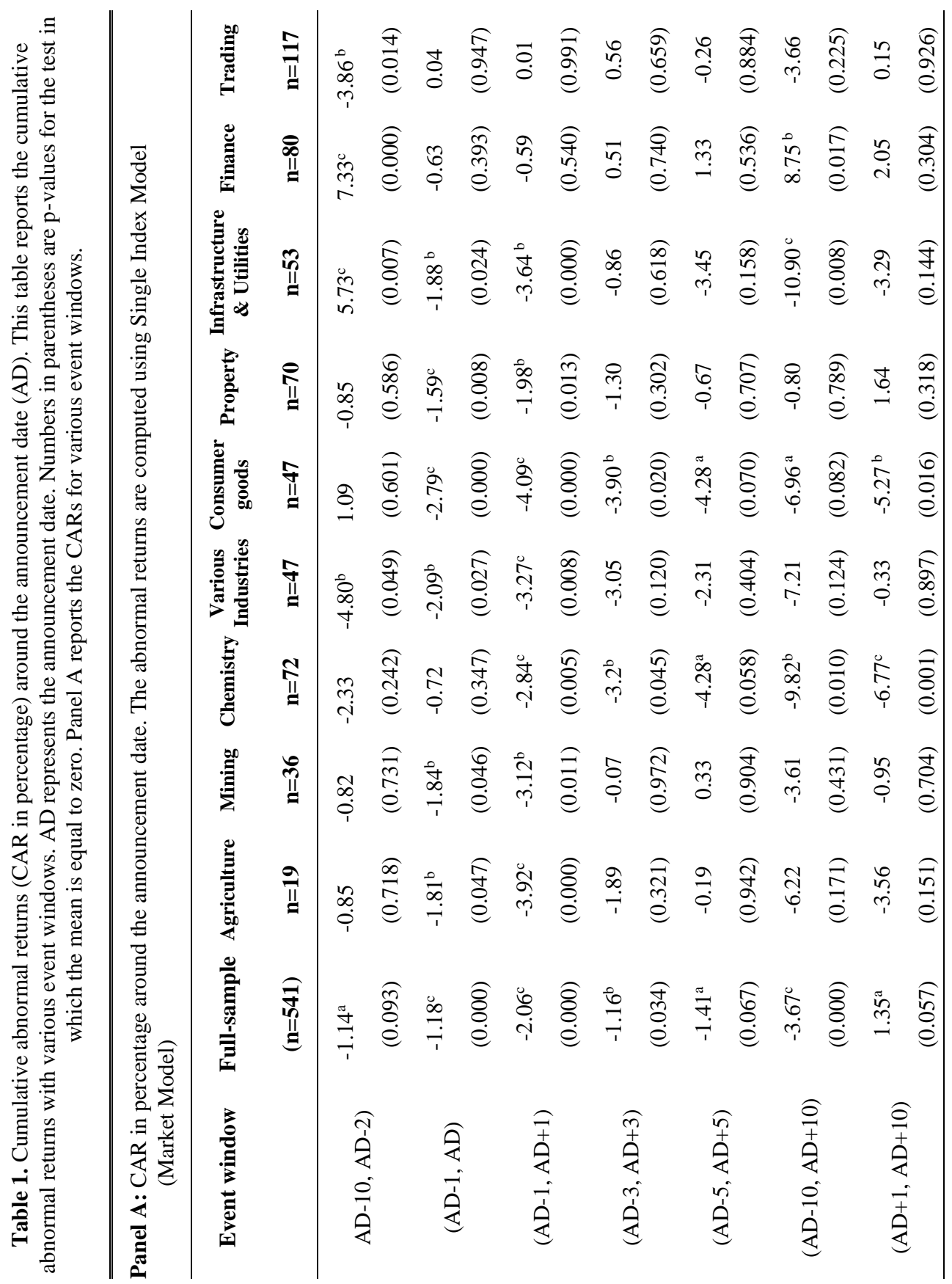




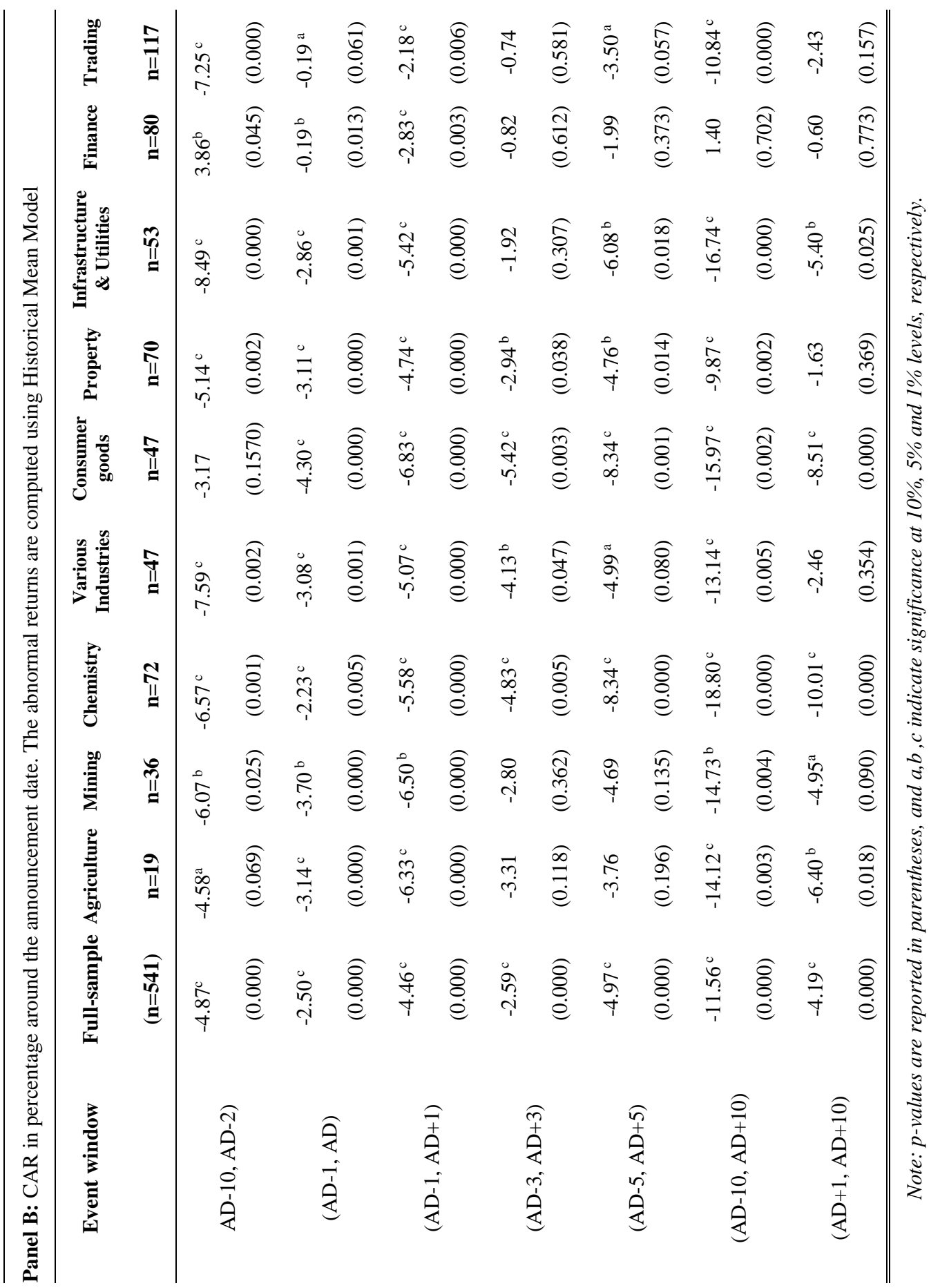


Table 1 reports the cumulative abnormal return (CARs) with different event windows. We report the results for the full sample and separately examine the differences in CARs for each industry classification. Panel A and Panel B report CARs and test differences using Single Index Model (Market Model) and Historical Mean Model, respectively.

For the full sample, we find an unclear pattern of CARs across different event windows either with Market or Historical Mean. In both models, we observe a significant and negative CAR before the announcement. The average CAR $(-10,-2)$ for both models, Market and Historical Mean, are significant with the values of $-1.14 \%$ and $4.87 \%$, respectively. Even though the President did not announce the case of Covid-19 yet, investors may anticipate the negative shock of the pandemic. The lockdown policy in several countries has perished the supply chains of production around the world (De Vito \& Gómez, 2020). In Panel A, we then only observe a marginal increase in the average CAR in the announcement date with a value of $1.18 \%$. We find a greater increase in average CAR $(-1,+1)$ with a value of $2.06 \%$. The results are qualitatively similar when using Historical Mean Model.

For the sub-sample analysis in Panel A, in general, we find a negative CAR across the industries for the event windows $(-1,0)$ and $(-1,1)$ except for the finance and trading industry. Other average CARs are remained negative and significant after the announcement except for agriculture, mining, property, infrastructure and utilities. In Panel B, using Historical Mean Model, we find similar results of negative market reactions across different industries. Moreover, we also find a negative and significant CAR $(-1,0)$ and $(-1,+1)$ for the finance and trading industry. While the negative average CARs remain until $(-10,+10)$, we do not find this effect in the finance industry. While the explanation is still unclear, the investors may observe that the economic impact on the finance industry may arise in the long-run. ${ }^{4}$

Overall, deploying the Covid-19 first case announcement by the Indonesian President, the results in Panel A and Panel B of Table 1 show the significant economic impact of the Covid-19 pandemic on the capital market. In most of the industries, the investors show a short-term negative reaction to deal with uncertainty. These results are consistent with the findings of Ashraf (2020b), Erdem (2020), Mazur et al. (2020) and Zhang et al. (2020) that reveal a systemic market reaction to the pandemic in Europe, US, and several Asian countries.

\section{CONCLUSION}

The Covid-19 has globally spread around the world and cause a potential long-term economic crisis. In this study, we examine how the Indonesian stock market has performed during the earlier stage of this pandemic. To this end, we use Indonesian listed firms and employ standard eventstudy methodology to examine the market reaction. Subsequently, we also examine whether the market reaction varies across industries. The present results clearly show the negative market reactions to anticipate unfavorable economic shocks. Furthermore, the negative reactions remain until ten days after the announcement of the first case of Covid-19 in Indonesia except for the finance industry. It is, therefore, unclear whether the impact on the finance industry will arise in

\footnotetext{
${ }^{4}$ In addition, the Indonesian Financial Services Authority (OJK), anticipate the domino's effect of Covid-19 pandemic by issuing regulation to relax certain requirements on banks' asset quality assessment concerning borrower affected by Covid- 19 .
} 
the long-term or as a result of policy interventions of the government. Hence, we suggest that further investigation needs to be carried out to examine the long-run effect of Covid-19 pandemic towards the finance industry.

While this is a plausible explanation of our results, there are two caveats. First, it should be noted that our empirical examination is preliminary and relies on limited data. In particular, because we only use two methods to measure abnormal return, additional methods are necessary to provide more robust results. Second, it is possible that there is different investors' reaction between stateowned and non-state-owned firms. Therefore, whether the fundamental firm's characteristics may significantly influence the investors' reactions is an important question to answer for future research.

\section{ACKNOWLEDGEMENT}

We are grateful to the Editor-in-Chief Evan Lau, and two anonymous reviewers for their insightful remarks. We offer our thanks to Harumi Puspa Rizky and Mega Wahyu Widawati for their assistance in data collection. The authors declare that they have no conflict of interests. Any remining errors are our own.

\section{REFERENCES}

Ali, M., Alam, N., \& Rizvi, S. A. R. (2020). Coronavirus (COVID-19) - An epidemic or pandemic for financial markets. Journal of Behavioral and Experimental Finance, 27, 100341. https://doi.org/10.1016/j.jbef.2020.100341

Ashraf, B. N. (2020a). Economic impact of government interventions during the COVID-19 pandemic: International evidence from financial markets. Journal of Behavioral and Experimental Finance, 27, 100371. https://doi.org/1016/j.jbef.2020.100371

Ashraf, B. N. (2020b). Stock markets' reaction to COVID-19: Cases or fatalities? Research in $\begin{array}{lllll}\text { International Business } & \text { and }\end{array}$ https://doi.org/10.1016/j.ribaf.2020.101249

Brown, S. J., \& Warner, J. B. (1985). Using daily stock returns: The case of event studies. Journal of Financial Economics, 14(1), 3-31. https://doi.org/10.1016/0304-405X(85)90042-X

De Vito, A., \& Gómez, J.-P. (2020). Estimating the COVID-19 cash crunch: Global evidence and policy. Journal of Accounting and Public Policy, 39(2), 106741. https://doi.org/10.1016/j.jaccpubpol.2020.106741

Erdem, O. (2020). Freedom and stock market performance during Covid-19 outbreak. Finance Research Letters, 36, 101671. https://doi.org/10.1016/j.frl.2020.101671

Goodell, J. W. (2020). COVID-19 and Finance: Agendas for future research. Finance Research Letters, 35, 101512. https://doi.org/10.1016/j.frl.2020.101512

Haroon, O., \& Rizvi, S. A. R. (2020). COVID-19: Media coverage and financial markets behavior-A sectoral inquiry. Journal of Behavioral and Experimental Finance, 27, 100343. https://doi.org/10.1016/j.jbef.2020.100343

MacKinlay, A. C. (1997). Event studies in economics and finance. Journal of Economic Literature 35(1), 13-39. 
Mazur, M., Dang, M., \& Vega, M. (2020). COVID-19 and the March 2020 Stock Market Crash. Evidence from S\&P1500. Finance Research Letters, 38, 101690. https://doi.org/10.1016/j.frl.2020.101690

Sharif, A., Aloui, C., \& Yarovaya, L. (2020). COVID-19 pandemic, oil prices, stock market, geopolitical risk and policy uncertainty nexus in the US economy: Fresh evidence from the wavelet-based approach. International Review of Financial Analysis, 70, 101496. https://doi.org/10.1016/j.irfa.2020.101496

Smith, R. D. (2006). Responding to global infectious disease outbreaks: Lessons from SARS on the role of risk perception, communication and management. Social Science \& Medicine, 63(12), 3113-3123. https://doi.org/10.1016/j.socscimed.2006.08.004

Zhang, D., Hu, M., \& Ji, Q. (2020). Financial markets under the global pandemic of COVID-19. Finance Research Letters, 36, 101528. https://doi.org/10.1016/j.frl.2020.101528 